\title{
Provenance changes between recent and glacial-time sediments in the Amundsen Sea embayment, West Antarctica: clay mineral assemblage evidence
}

\author{
WERNER EHRMANN ${ }^{1}$, CLAUS-DIETER HILLENBRAND ${ }^{2}$, JAMES A. SMITH ${ }^{2}$, ALASTAIR G.C. GRAHAM ${ }^{2}$, \\ GERHARD KUHN ${ }^{3}$ and ROBERT D. LARTER ${ }^{2}$ \\ ${ }^{1}$ University of Leipzig, Institute of Geophysics and Geology, Talstraße 35, D-04103 Leipzig, Germany \\ ${ }^{2}$ British Antarctic Survey, NERC, High Cross, Madingley Road, Cambridge CB3 OET, UK \\ ${ }^{3}$ Alfred Wegener Institute for Polar and Marine Research, Am Alten Hafen 26, D-27568 Bremerhaven, Germany \\ ehrmann@rz.uni-leipzig.de
}

\begin{abstract}
The Amundsen Sea embayment is a probable site for the initiation of a future collapse of the West Antarctic Ice Sheet. This paper contributes to a better understanding of the transport pathways of subglacial sediments into this embayment at present and during the last glacial period. It discusses the clay mineral composition of sediment samples taken from the seafloor surface and marine cores in order to decipher spatial and temporal changes in the sediment provenance. The most striking feature in the presentday clay mineral distribution is the high concentration of kaolinite, which is mainly supplied by the Thwaites Glacier system and indicates the presence of hitherto unknown kaolinite-bearing sedimentary strata in the hinterland, probably in the Byrd Subglacial Basin. The main illite input is via the Pine Island Glacier. Smectite originates from the erosion of volcanic rocks in Ellsworth Land and western Marie Byrd Land. The clay mineral assemblages in diamictons deposited during the last glacial period are distinctly different from those in corresponding surface sediments. This relationship indicates that glacial sediment sources were different from modern ones, which could reflect changes in the catchment areas of the glaciers and ice streams.
\end{abstract}

Received 30 July 2010, accepted 25 March 2011, first published online 18 May 2011

Key words: catchment, chlorite, ice divide migration, illite, kaolinite, smectite

\section{Introduction}

The possible instability of the largely marine based West Antarctic Ice Sheet (WAIS) and the potential impact of its partial or complete collapse on global sea level has been a major focus of geological and glaciological studies in Antarctica during the past decade (e.g. Oppenheimer 1998, Thomas et al. 2004, Rignot et al. 2008, Vaughan 2008, Bamber et al. 2009). It has been suggested that the Amundsen Sea embayment (ASE) is the most likely site for the initiation of a WAIS collapse (Vaughan 2008). We contribute to a better understanding of the ASE by investigating the provenance of the recent and the glacialtime sediments and thus by providing information on the past configuration of the WAIS.

The ASE is located on the Pacific margin of Antarctica. It includes a c. 200-450 km wide continental shelf, north of the modern ice front (Fig. 1). To the north of the ASE shelf, the Antarctic Circumpolar Current (ACC) flows to the east, extending to $c .70^{\circ} \mathrm{S}$ (Walker et al. 2007). The westward flowing Antarctic Coastal Current is apparently not very pronounced in the ASE, but is assumed to flow, at least seasonally, along the ASE shelf. Circumpolar Deep Water (CDW) floods the continental shelf of the ASE through deep cross-shelf troughs (Walker et al. 2007, Thoma et al. 2008).
Approximately $25 \%$ of the area of the WAIS drains into the ASE. Melting of all the ice in this sector would raise global sea level by $c$. $1.5 \mathrm{~m}$ (Vaughan 2008). The main drainage is through a number of fast flowing ice streams including Pine Island Glacier, Thwaites Glacier and Smith Glacier. The Getz, Dotson, Crosson, Cosgrove and Abbot ice shelves fringe the coast of the ASE (Fig. 1). At present, some of the glaciers flowing into the ASE (mainly Thwaites, Smith and Pine Island) show thinning, flow acceleration and/or rapid grounding line retreats (e.g. Thomas et al. 2004, Rignot et al. 2008, Vaughan 2008, Pritchard et al. 2009). These changes are probably triggered by ice shelf basal melting caused by relatively warm CDW protruding far onto the continental shelf (Rignot \& Jacobs 2002, Thoma et al. 2008, Vaughan 2008) and amplified by a reverse gradient basal slope (Schoof 2007).

Prominent $1000-1600 \mathrm{~m}$ deep troughs characterize the inner shelf of the ASE north of the Getz A and B ice shelves, Dotson Ice Shelf, Thwaites Glacier and Pine Island Glacier. They converge to shallower and broader troughs on the mid-shelf and continue to the shelf break, where they are still $\geq 500 \mathrm{~m}$ deep (Fig. 1; Lowe \& Anderson 2002, Evans et al. 2006, Graham et al. 2009, 2010, Larter et al. 2009). The present morphology of the Amundsen Sea shelf 


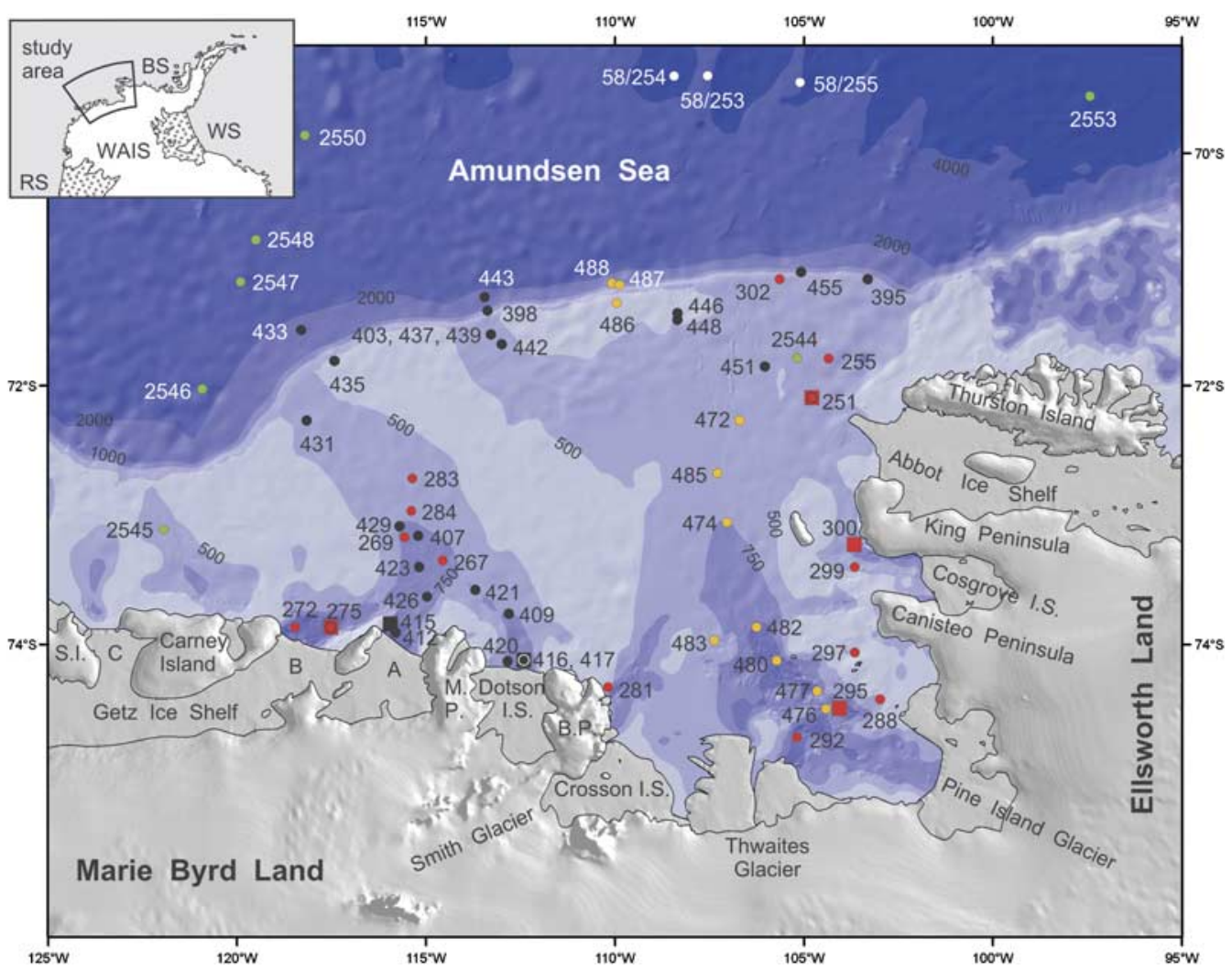

Fig. 1. Map of the Amundsen Sea embayment with sample locations. Samples were recovered during expeditions JR141 (black), JR179 (yellow), ANT-XI/3 (green), ANT-XVIII/5a (white) and ANT-XXIII/4 (red). Core identification numbers have been simplified (cf. Table I). Dots indicate locations of surface sediment samples, squares show locations of sediment cores. The bathymetry is given by different colours for $500 \mathrm{~m}, 750 \mathrm{~m}, 1000 \mathrm{~m}, 2000 \mathrm{~m}$, and $4000 \mathrm{~m}$. Abbreviations: B.P. = Bear Peninsula, M.P. = Martin Peninsula, I.S. = Ice Shelf, S.I. = Siple Island. Getz Ice Shelf is subdivided into compartments A, B and C. Inset map: BS $=$ Bellingshausen Sea, RS = Ross Sea, WAIS $=$ West Antarctic Ice Sheet, WS = Weddell Sea.

is mainly inherited from past glacial periods, in particular from the Last Glacial Maximum, when grounded ice reached the outer shelf and probably the shelf edge, and fast flowing ice streams scoured the troughs (Wellner et al. 2001, Lowe \& Anderson 2002, Evans et al. 2006, Graham et al. 2009, 2010, Larter et al. 2009). Lowe \& Anderson (2002) suggested that in the eastern ASE ice retreated gradually in a first step from the outer shelf, before pausing on a bathymetric high on the middle shelf by $c .14 .5 \mathrm{ka}$ before present (BP, corrected ${ }^{14} \mathrm{C}$ age). In a second step the ice retreated rapidly and reached the inner shelf at about $8.9 \mathrm{ka}$ BP (corrected ${ }^{14} \mathrm{C}$ age). Recent analyses of new multibeam data from the eastern ASE reveal several grounding line wedges, suggesting a stepwise retreat of the grounding line during the last deglaciation (Graham et al. 2010). Grounding zone wedges have also been documented in the western ASE and also suggest a stepwise retreat (Graham et al. 2009, Weigelt et al. 2009), although the current dating resolution (e.g. Smith et al. 2011) is not sufficient to constrain the timing of any potential still-stands. The inner shelf north of the Getz A/B and Dotson ice shelves had become free of grounded ice by $c$. 10.8-8.9 ka BP and
$9.9 \mathrm{ka}$ BP, respectively (corrected ${ }^{14} \mathrm{C}$ ages; Hillenbrand et al. 2010, Smith et al. 2011).

In order to contribute to a better understanding of the former and present-day subglacial sediment transport via glaciers into the ASE, we present an extended dataset on the distribution of clay minerals in surface sediments (Figs 2 \& 3) and in cores that penetrated sediments deposited during the last glacial period (Figs 4 \& 5). In Antarctica, the dominance of physical weathering combined with the general absence of authigenic clay mineral formation (e.g. Chamley 1989, Petschick et al. 1996, Fagel 2007) make clay mineral assemblages in proximal glaciomarine sediments useful tools for reconstructing source areas and sediment transport pathways. We follow the well-established approach for identifying clay mineral source regions in Antarctica, where very little information is available about the geology of the hinterland, by sampling and analysing undisturbed surface sediment samples from coastal areas (e.g. Gingele et al. 1997, Hillenbrand \& Ehrmann 2002, Hillenbrand et al. 2003, 2009b). This approach assumes that most of the terrigenous debris melts out near the coast and is transported farther seaward by ocean currents, thus allowing mixing 
and dilution. Furthermore, clay mineral assemblages in more distal settings may be influenced by sediment erosion and recycling on the Antarctic shelf (Hillenbrand et al. 2009b).

So far, no detailed or systematic clay mineral study has been carried out in the ASE. However, clay mineral data from glaciomarine and subglacial sediments recovered in the eastern ASE show a wide range in the abundance of the different clay minerals (Lowe \& Anderson 2002). A remarkable feature of this study was the high kaolinite concentration of $10-16 \%$. Even higher concentrations were found in a seafloor surface sample from the western ASE shelf and in Quaternary sedimentary sequences recovered from the continental rise offshore from the ASE (Hillenbrand et al. 2002, 2003, 2009a; Table I). However, the source for the kaolinite is not yet known.

Our main objectives are to map the modern distribution of the clay minerals kaolinite, smectite, chlorite and illite on the West Antarctic continental margin of the ASE in more detail and to identify possible sources of the clay minerals. The occurrence of kaolinite is especially important, because it cannot form under glacial conditions and therefore implies the presence of pre-Oligocene sedimentary strata (or sediments containing recycled pre-Oligocene detritus) beneath the ice. The presence of a sedimentary substrate, in turn, is an important factor affecting the dynamics of fast flowing glaciers and ice streams (e.g. Studinger et al. 2001, Anandakrishnan \& Winberry 2004). Furthermore we analysed the clay mineral composition in sediment cores recovered directly in front of the present-day ice margin. This should tell us whether the identified modern sources have remained constant through time, and particularly during and at the end of the last glacial period.

\section{Material and methods}

We investigated seafloor surface samples recovered with box and multiple corers from the continental shelf in the ASE and the adjacent continental slope and rise. The sediment surfaces showed no signs of coring disturbances or sediment loss due to coring and core retrieval. Additionally, we investigated sedimentary sequences recovered with gravity and vibro corers from the ASE shelf (e.g. Smith et al. 2011). The samples were collected during cruises JR141 and JR179 of the RRS James Clark Ross in 2006 and 2008 and during cruises ANT-XVIII/5a and ANT-XXIII/4 of the RV Polarstern in 2001 and 2006 (Fig. 1, Table I).

Sample processing and analyses followed standard procedures (e.g. Ehrmann et al. 1992, Petschick et al. 1996). We separated the clay fraction $(<2 \mu \mathrm{m})$ from the bulk sediment in settling tubes and mixed $40 \mathrm{mg}$ clay suspension with $1 \mathrm{ml}$ of an internal standard $\left(0.04 \% \mathrm{MoS}_{2}\right.$ suspension). We then mounted the samples as texturally oriented aggregates by rapidly filtering the suspension through a membrane filter $(0.20 \mu \mathrm{m}$ pore width $)$, dried the filter cakes at $50^{\circ} \mathrm{C}$, fixed them on aluminium tiles and exposed them to ethylene glycol vapour at a temperature of $60^{\circ} \mathrm{C}$ for at least $18 \mathrm{~h} \mathrm{immediately} \mathrm{before} \mathrm{the} \mathrm{X-ray}$ analyses. The measurements were conducted on a diffractometer system Rigaku New Miniflex with $\mathrm{CoK} \alpha$ radiation $(30 \mathrm{kV}, 15 \mathrm{~mA})$. We first $\mathrm{X}$-rayed the samples in the range $3-40^{\circ} 2 \Theta$, with a step size of $0.02^{\circ} 2 \Theta$ and a measuring time of two seconds per step. Then we measured the range $27.5-30.6^{\circ} 2 \Theta$ with a step size of $0.01^{\circ} 2 \Theta$ and a measuring time of four seconds per step in order to better resolve the (002) peak of kaolinite and the (004) peak of chlorite. The X-ray diffractograms were evaluated using the interactive "MacDiff" software (Petschick 2001). We identified the main clay mineral groups by their basal reflections at $16.5 \AA$ (smectite, after glycolisation), 10 and $5 \AA$ (illite), 14.2, 7, 4.72 and $3.54 \AA$ (chlorite), and 7 and $3.58 \AA$ (kaolinite) after the diffractograms had been adjusted to the $\mathrm{MoS}_{2}$ peak at $6.15 \AA$. For semiquantitative evaluations of the clay mineral assemblages, we used empirically estimated weighting factors on the integrated peak areas of the individual clay mineral reflections (Biscaye 1964, 1965). We determined the crystallinity of illite by calculating the integral breadth (IB, $\Delta^{\circ} 2 \theta$ ) of the $10 \AA$ peak. High IB values indicate poor crystallinities, whereas low values indicate good crystallinities. Furthermore, we inferred the illite composition from the $5 / 10 \AA$ peak area ratio. Values $>0.4$ correspond to Al-rich illites (muscovite). The ratio decreases with $\mathrm{Mg}$ and Fe substituting the octahedral Al. Magnesium and iron-rich illites (biotite) have values $<0.15$ (Esquevin 1969).

By preparing, analysing and evaluating samples six times, we achieved a standard deviation of $c .1 \%$ for the concentrations of smectite, chlorite and kaolinite, and of c. $1.5 \%$ for illite. The standard deviation for the $5 / 10 \AA$ peak area ratios is $c .0 .05$ and that for illite IB c. $0.02 \Delta^{\circ} 2 \theta$.

All data are stored in the PANGAEA database of the Alfred Wegener Institute for Polar and Marine Research, Bremerhaven (Germany) at http://doi.pangaea.de/10.1594/ PANGAEA.755199.

Additionally, we included some published clay mineral data of seafloor surface samples that were taken in the Amundsen Sea during cruise ANT-XI/3 of RV Polarstern in 1994 (Hillenbrand et al. 2003, Table I). The published data are compatible with our dataset, because sample preparation, XRD investigation and evaluation followed identical procedures.

\section{Clay mineral distribution in the surface sediments}

\section{Kaolinite}

The most striking feature in the distribution of the clay minerals in surface sediments of the ASE is the high concentration of kaolinite (7-29\%, Table I), in particular when compared to other parts of the West Antarctic continental margin, as for example the eastern and southern Bellingshausen Sea and the Weddell Sea (Ehrmann et al. 1992, Petschick et al. 1996, Hillenbrand \& Ehrmann 2002, Hillenbrand et al. 2009b). 

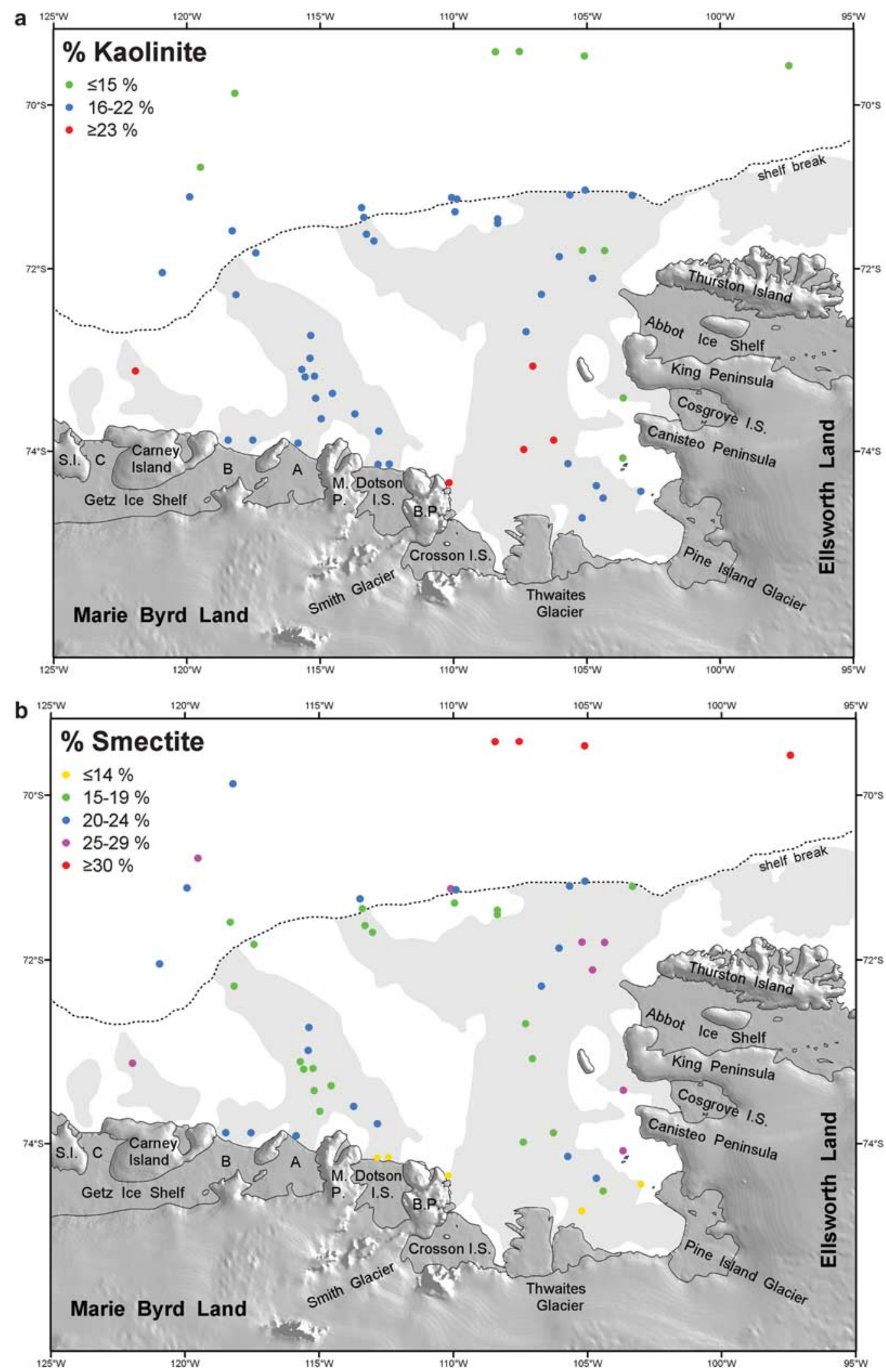

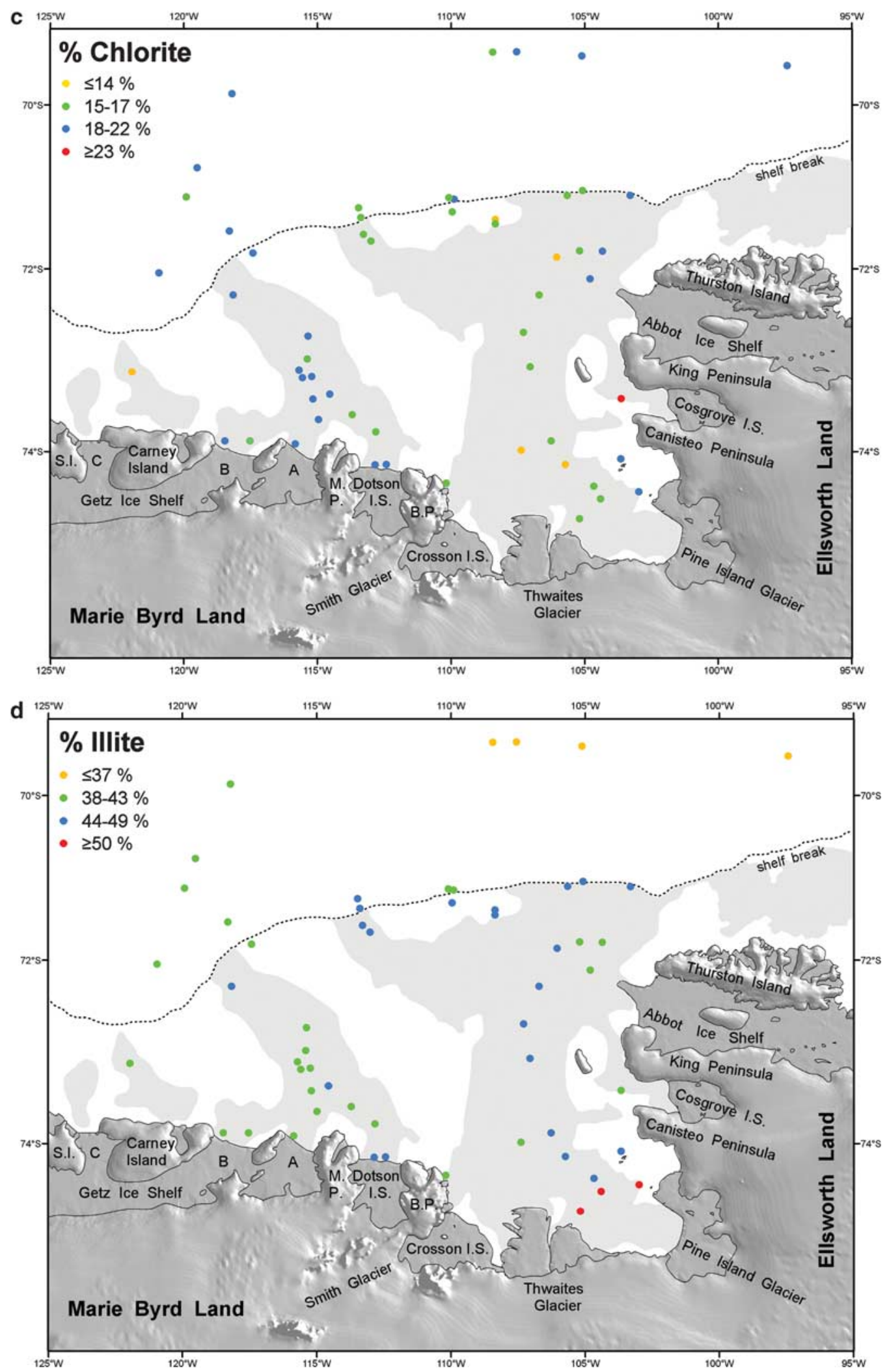

Fig. 2. Percentage distributions of the clay minerals a. kaolinite, b. smectite, c. chlorite, and d. illite in the $<2 \mu \mathrm{m}$ fraction of the surface sediments in the Amundsen Sea. Shelf areas with water depths $>500 \mathrm{~m}$ are shaded. 

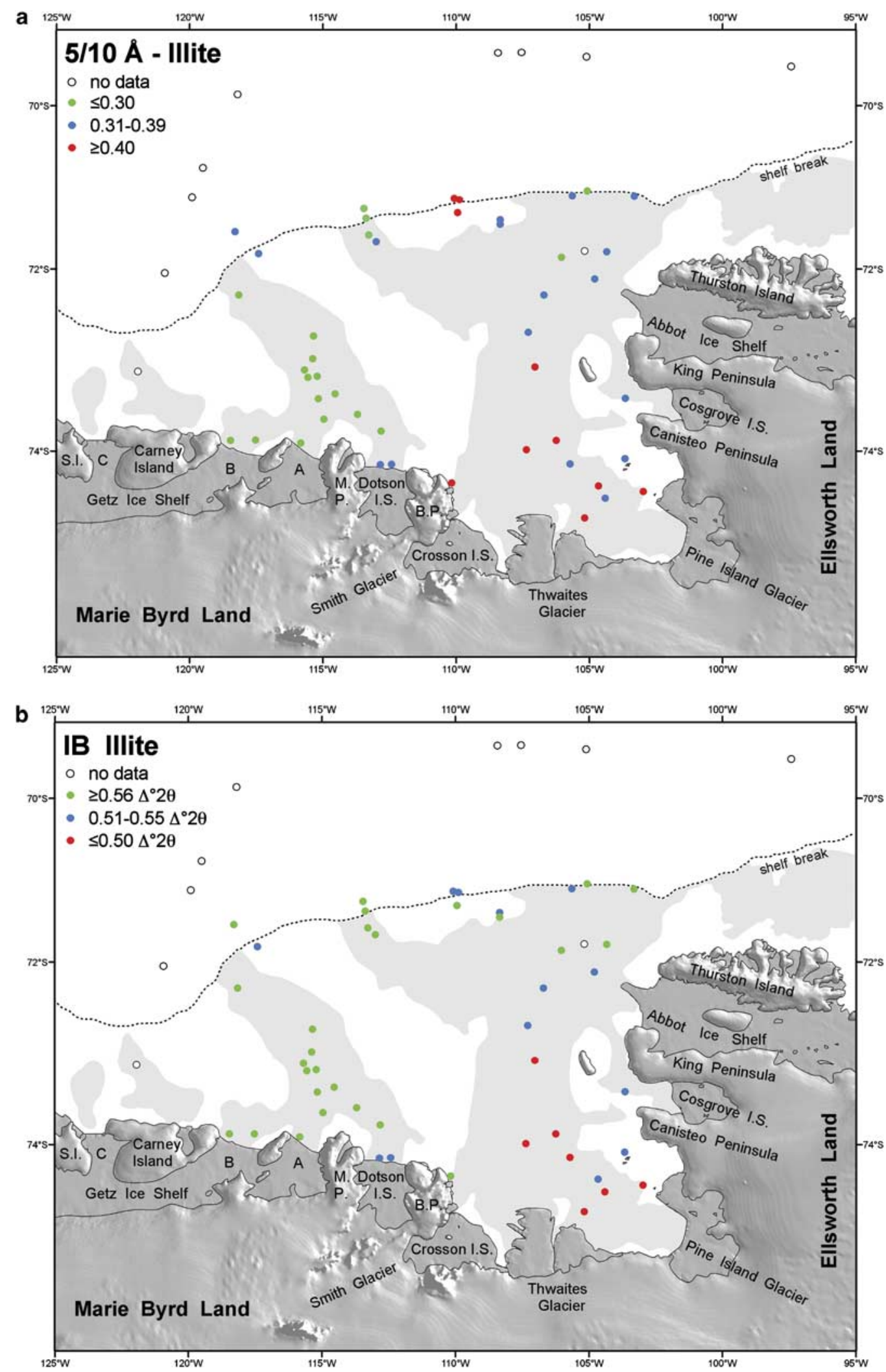

Fig. 3. Distribution of a. the $5 / 10 \AA$ ratio of illite, and b. the illite crystallinity (integral breadth, IB, in $\Delta^{\circ} 2 \theta$ ) in the $<2 \mu \mathrm{m}$ fraction of the surface sediments in the Amundsen Sea. Shelf areas with water depths $>500 \mathrm{~m}$ are shaded. 

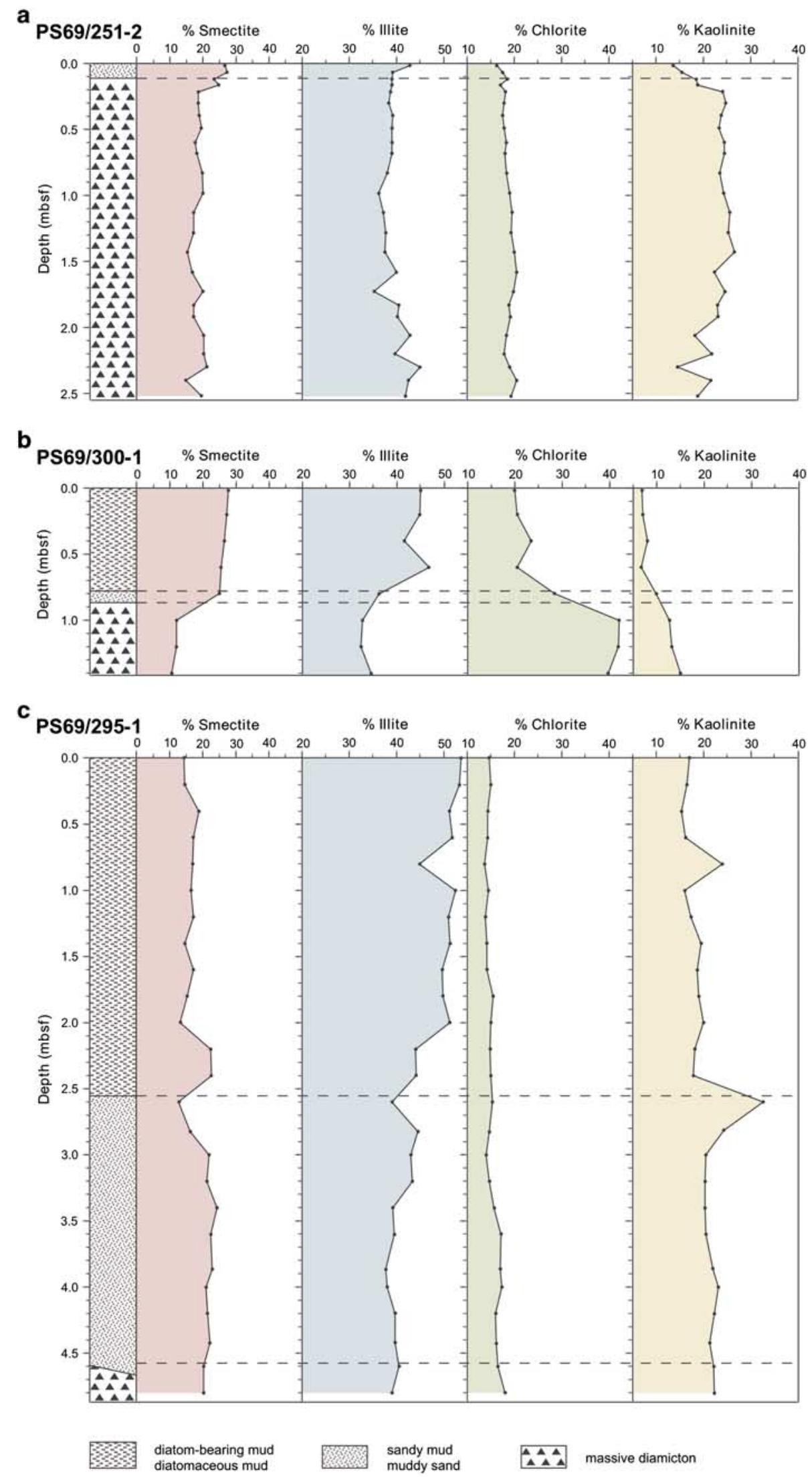

Fig. 4. Clay mineral composition of late Quaternary sediments in cores a. PS69/251-2, b. PS69/300-1, and c. PS69/295-1 from the eastern Amundsen Sea embayment. 

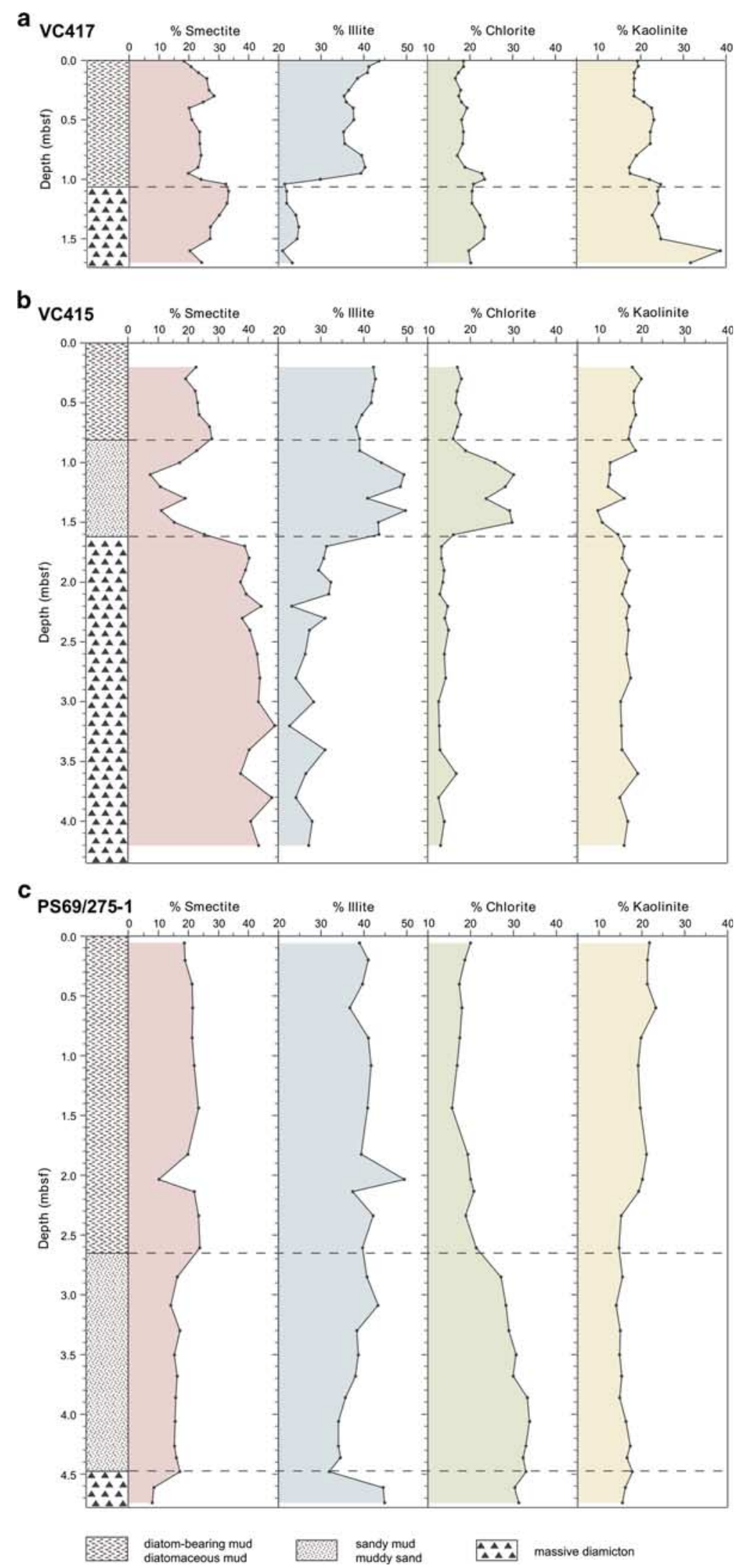

Fig. 5. Clay mineral composition of late Quaternary sediments in cores a. VC417, b. VC415, and c. PS69/275-1 from the western Amundsen Sea embayment. 
Table I. Metadata for the sediment samples from the Amundsen Sea embayment.

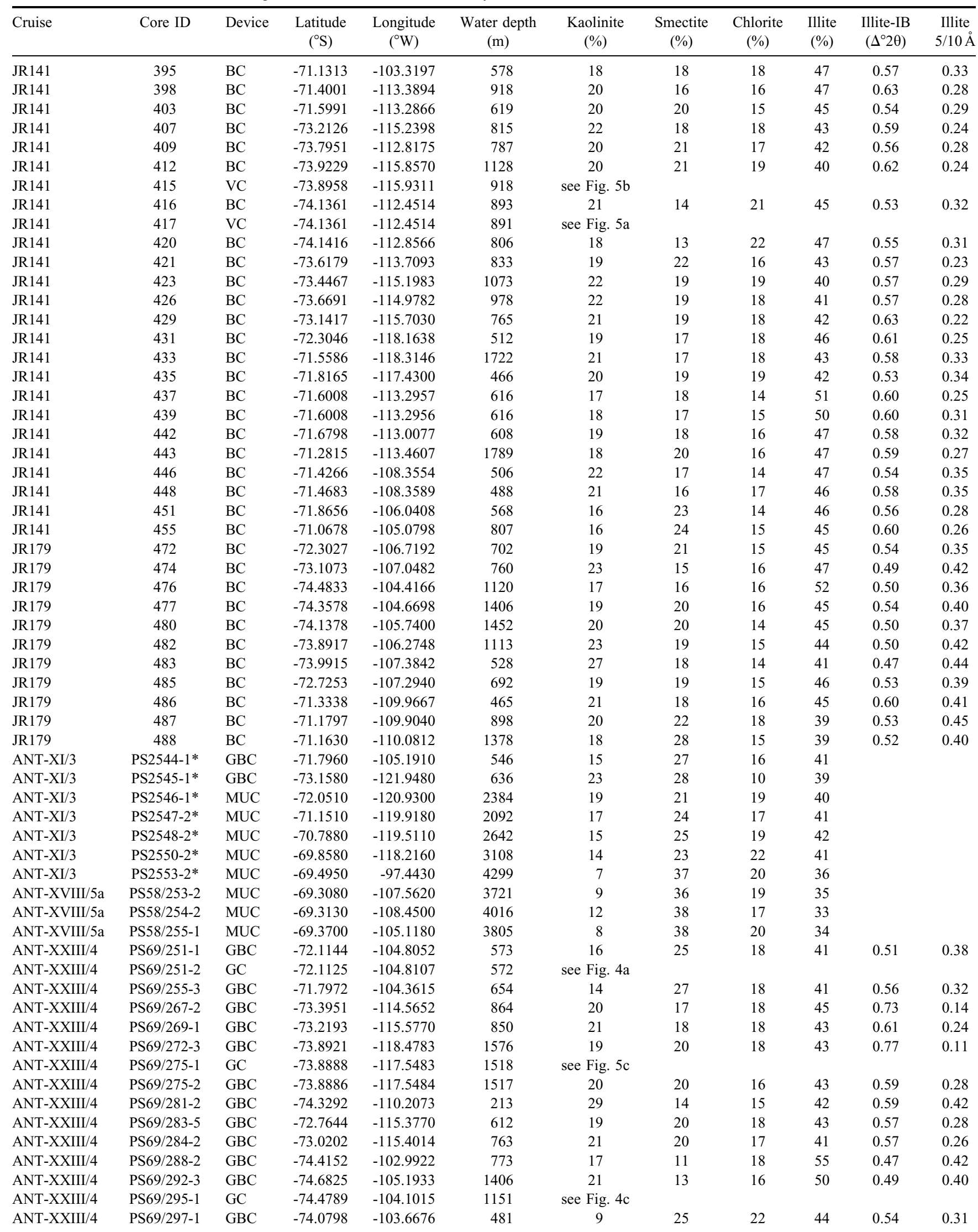


Table I. Continued

\begin{tabular}{|c|c|c|c|c|c|c|c|c|c|c|c|}
\hline Cruise & Core ID & Device & $\begin{array}{l}\text { Latitude } \\
\quad\left({ }^{\circ} \mathrm{S}\right)\end{array}$ & $\begin{array}{l}\text { Longitude } \\
\left({ }^{\circ} \mathrm{W}\right)\end{array}$ & $\begin{array}{l}\text { Water depth } \\
\quad(\mathrm{m})\end{array}$ & $\begin{array}{l}\text { Kaolinite } \\
(\%)\end{array}$ & $\begin{array}{c}\text { Smectite } \\
(\%)\end{array}$ & $\begin{array}{c}\text { Chlorite } \\
(\%)\end{array}$ & $\begin{array}{l}\text { Illite } \\
(\%)\end{array}$ & $\begin{array}{l}\text { Illite-IB } \\
\left(\Delta^{\circ} 2 \theta\right)\end{array}$ & $\begin{array}{l}\text { Illite } \\
\text { 5/10 }\end{array}$ \\
\hline ANT-XXIII/4 & PS69/299-1 & GBC & -73.4437 & -103.6482 & 718 & 7 & 26 & 25 & 41 & 0.53 & 0.33 \\
\hline ANT-XXIII/4 & PS69/302-3 & GBC & -71.1317 & -105.6383 & 565 & 19 & 21 & 16 & 44 & 0.54 & 0.34 \\
\hline
\end{tabular}

$\mathrm{BC}=$ box corer, $\mathrm{GBC}=$ giant box corer, $\mathrm{GC}=$ gravity corer, $\mathrm{MUC}=$ multiple corer, $\mathrm{VC}=$ vibro corer. *data from Hillenbrand et al. 2003.

Kaolinite is a product of chemical weathering, characteristic of moist, temperate to tropical regions, and cannot form under polar conditions. However, because kaolinite is resistant to physical weathering, it is frequently found as a recycling product in polar environments. Its presence indicates the erosion of palaeosoils, sediments or sedimentary rocks that contain kaolinite as a common component. Such sediments may have formed in Antarctica at times when chemical weathering still prevailed, i.e. before the onset of continental glaciation in East Antarctica in earliest Oligocene time, which correlates with a drastic intensification of physical weathering conditions
(Ehrmann et al. 1992, Dingle \& Lavelle 1998, Forsberg et al. 2008).

The highest kaolinite concentrations (up to 29\%) appear north of the Thwaites Glacier system and north-east of the Getz C Ice Shelf (Fig. 2a). Intermediate values of around $20 \%$ occur in front of Pine Island Glacier, north of the Dotson and the Getz A and B ice shelves, on the outer continental shelf and on the upper continental slope. The lowest kaolinite contents are found in the easternmost ASE near the Cosgrove and Abbot ice shelves, and on the upper continental rise.

We can exclude a kaolinite delivery to the shelf of the ASE by ocean currents from the west and north, respectively,

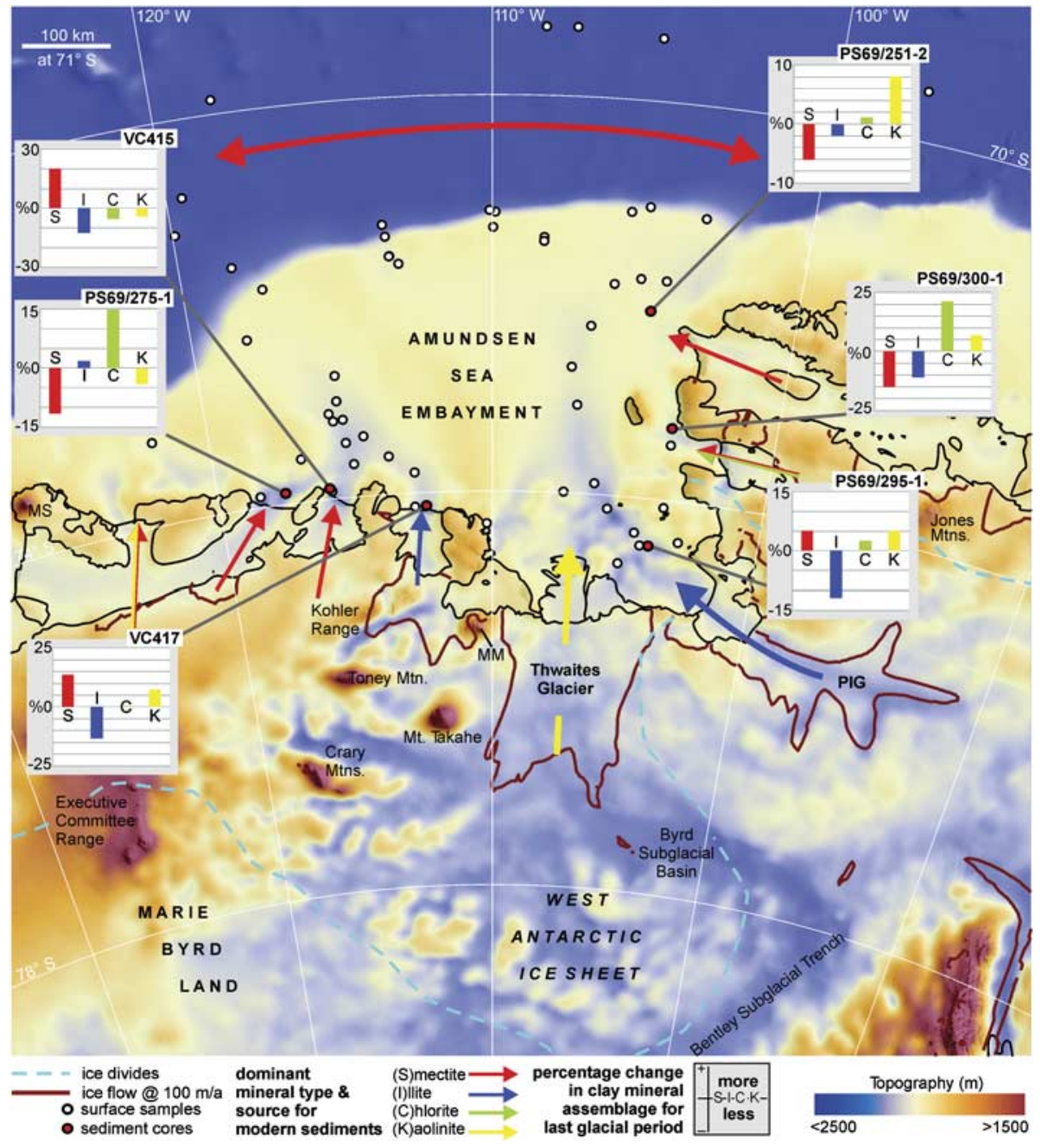

Fig. 6. Compilation of the major modern source areas for the main clay mineral groups in the Amundsen Sea embayment (arrows), and relative changes in the clay mineral assemblages for the last glacial period (histograms). $\mathrm{MM}=$ Mount Murphy, MS = Mount Siple, $\mathrm{PIG}=$ Pine Island Glacier. 
because i) the southern boundary of the eastward flowing ACC is located at $c .70^{\circ} \mathrm{S}$ (Walker et al. 2007, Thoma et al. 2008), and ii) the kaolinite concentrations in the deep sea are much lower than on the shelf (Fig. 2a). A supply of kaolinite from the southern Bellingshausen Sea by westward flowing currents can also be excluded, because of the low kaolinite concentrations of typically $<5 \%$ in surface sediments in this region (Hillenbrand et al. 2009b).

The concentration pattern in our study area implies that the kaolinite has to be sourced in Marie Byrd Land. The highest concentrations on the inner shelf occur in front of the Thwaites Glacier tongue and the Getz C Ice Shelf, indicating a source from these specific drainage areas. In contrast, there is no obvious recent kaolinite source in north-west Ellsworth Land, since its margin (i.e. west of Abbot and Cosgrove ice shelves) exhibits the lowest kaolinite concentrations of the entire ASE.

In Marie Byrd Land, probable source rocks, i.e. kaolinitebearing pre-glacial, but non-metamorphic sedimentary strata, are not known from outcrops. Plutonic and metamorphic basement rocks together with Cenozoic volcanic rocks dominate the geology (LeMasurier \& Rex 1991, Pankhurst et al. 1998, Mukasa \& Dalziel 2000). However, it has been suggested that sedimentary rocks are present beneath the WAIS, especially in the Byrd Subglacial Basin (Clarke et al. 1997, Hillenbrand et al. 2003; Fig. 6). Our new findings demonstrate that the Byrd Subglacial Basin, which is connected to the Thwaites Glacier system (Holt et al. 2006), is likely to be a more important kaolinite source for the ASE than the Bentley Subglacial Trench, which drains into the ASE via Pine Island Glacier (Vaughan et al. 2006, Fig. 6). Both the Byrd Subglacial Basin and the Bentley Subglacial Trench have been described as features with an infill of $c .500 \mathrm{~m}$ of unconsolidated sediments of unknown age and unknown composition, underlain by continental crust (Winberry \& Anandakrishnan 2004, Bell et al. 2006, LeMasurier 2008).

Furthermore, the kaolinite concentrations of c. $20 \%$ in front of the Dotson, Getz A and Getz B ice shelves, and the even higher concentrations in front of the Getz C Ice Shelf imply that kaolinite-bearing source rocks in Marie Byrd Land are not restricted to the Byrd Subglacial Basin. Mukasa \& Dalziel (2000) presented evidence for old sedimentary rocks underlying the continental margin of Marie Byrd Land. It is possible that these rocks crop out subglacially and are eroded by ice masses draining into the ASE (cf. Hillenbrand et al. 2003).

\section{Smectite}

Smectite occurs with contents of $11-38 \%$ in surface sediments of the investigated area (Table I). This clay mineral normally forms by hydrolysis under warm, humid to cold, dry conditions in areas with slow moving water and contrasting dry and wet seasons. In glaciomarine sediments, high smectite contents have been reported from areas dominated by volcanic rocks in the hinterland (e.g. Ehrmann et al. 1992).

Highest smectite concentrations of $>35 \%$ are found on the upper continental rise (Fig. 2b). Hillenbrand et al. (2003) attributed the high smectite content at site PS2553 to a supply from Peter I Island $\left(68^{\circ} 50^{\prime} \mathrm{S}, 90^{\circ} 34^{\prime} \mathrm{W}\right)$ by westward flowing bottom currents. However, our new data show an extension of high smectite contents even further westward. It is unclear, however, if this distribution pattern is due to an westward supply from Peter I Island, an eastward supply with the ACC from further west (i.e. from the Ross Sea region), or a southward supply of smectiterich clay from the sub-Antarctic part of the South Pacific basin, where smectite-rich sediments were reported by Nayudu (1971).

On the ASE shelf, enhanced smectite concentrations of $\geq 25 \%$ are found near the Abbot and Cosgrove ice shelves (Fig. 2b). Probable sources are the widespread subglacial and subaerial Cenozoic volcanic rocks in Ellsworth Land, for example in the Jones Mountains (e.g. LeMasurier \& Thomson 1990, Tingey 1991; Fig. 6). The Mesozoic volcanic rocks of Thurston Island (Storey et al. 1991) may also contribute to the high smectite content in the north-east ASE. Similarly high smectite concentrations are found north-east of the Getz C Ice Shelf in the western ASE (Fig. 2b). In this region, the high smectite concentrations possibly derive from the extensive Cenozoic volcanic rocks that crop out on Siple Island (Mount Siple volcano) and which are also present beneath the ice (LeMasurier \& Thomson 1990, Tingey 1991, Wilch et al. 1999).

In contrast, the rocks of the Cenozoic Marie Byrd Land volcanic province (LeMasurier \& Rex 1991) in eastern Marie Byrd Land seem to be a less important smectite source. Thus, only intermediate smectite contents of c. $20-22 \%$ are observed north of the Getz A and B ice shelves. The lowest smectite concentrations of $\leq 14 \%$ are observed north of the Dotson Ice Shelf, Bear Peninsula and the Thwaites Glacier system, which have the volcanoes of Kohler Range, Mount Murphy, Mount Takahe, Crary Mountains and Toney Mountain in their catchment area (LeMasurier \& Rex 1991, Wilch et al. 1999, Dunbar et al. 2008; Fig. 6), and north of Pine Island Glacier, which has the subaerial and subglacial volcanoes of the Hudson Mountains in its catchment area (LeMasurier \& Thomson 1990, Fig. 6).

As observed on the shelf of the southern Bellingshausen Sea (Hillenbrand et al. 2009b) and on the East Antarctic continental margin (Robert \& Maillot 1990), the erosion of old sedimentary strata may provide additional smectite onto the ASE shelf. However, the negative correlation between smectite and kaolinite on the inner shelf north of the Thwaites Glacier system (Fig. 2b) suggests that the smectite there is mainly derived from volcanic source rocks. 


\section{Chlorite}

Chlorite occurs in surface sediments of the study area with concentrations of 10-25\% (Table I). Chlorite is a detrital clay mineral, which typically derives from physical weathering of low-grade, chlorite-bearing metamorphic and basic rocks.

Elevated chlorite contents are found in the easternmost ASE with a maximum of $25 \%$ offshore from the Cosgrove Ice Shelf (Fig. 2c). Together with the high smectite content, this may indicate an origin from basic volcanic rocks, although metamorphic rocks (Tingey 1991) may also contribute some chlorite. Elevated chlorite concentrations also extend from the Getz A and Dotson ice shelves northwards across the shelf. As the smectite content is low and the illite content is high in this area, the chlorite is probably derived from weathering of metamorphic rocks that are present in the West Antarctic hinterland (Pankhurst et al. 1998).

In contrast, the Thwaites Glacier system and the Pine Island Glacier apparently deliver only minor amounts of chlorite. Only $\leq 14 \%$ chlorite occurs in front of the Thwaites Glacier outlet and c. $16 \%$ in front of Pine Island Glacier. Thus, metamorphic or basic volcanic rocks in the hinterland play only a subordinate role for offshore sediment supply. The low chlorite concentrations extend from the ice front across the middle shelf to the shelf break.

A low chlorite concentration of $c .10 \%$ characterizes the sample north of the Getz C Ice Shelf in the westernmost ASE. Together with the relatively high smectite and kaolinite concentrations this chlorite minimum suggests a source that is dominated by volcanic and sedimentary rocks. The erosion of low-grade metamorphic rocks probably plays only a minor role.

\section{Illite}

Illite occurs with concentrations of $33-55 \%$ (Table I) and is the most abundant clay mineral in modern sediments of the ASE. Illite is a detrital clay mineral. It derives particularly from physical weathering of crystalline rocks and therefore is abundant in marine sediments of the high latitudes. Typical sources are acidic rocks, such as granitoids and gneisses.

The distribution map clearly indicates that the main illite input is from easternmost Marie Byrd Land and possibly from the Bentley Subglacial Trench (Figs 2d \& 6). Concentrations of around $45 \%$ characterize the shelf areas in front of the Dotson Ice Shelf and between the Thwaites Glacier and the shelf break. Assemblages consisting of up to 55\% illite are found offshore from Pine Island Glacier. Probable source rocks are the Palaeozoic, Triassic and Cretaceous basement rocks of mainly granitic and granodioritic composition that are widespread in Marie Byrd Land (Pankhurst et al. 1998, Mukasa \& Dalziel 2000), and possibly rocks forming the continental crust that underlies the Bentley Subglacial Trench (Winberry \& Anandakrishnan 2004).
Intermediate illite contents of around $40 \%$ occur in front of the Getz Ice Shelf, as well as offshore from the Cosgrove and Abbot ice shelves. Low illite concentrations occur on the continental slope and rise offshore from the eastern ASE.

It is interesting to note that the $5 / 10 \AA$ ratio is generally $\leq 0.30$ on the western ASE shelf in front of the Getz Ice Shelf, whereas on the eastern ASE shelf the ratios are higher (Table I, Fig. 3a). The highest values of $\geq 0.40$ occur in samples from sites in front of the Thwaites Glacier system and the Pine Island Glacier and on the outer shelf/slope. Along the coast of Ellsworth Land and in the north-easternmost ASE the 5/10 $\mathrm{\AA}$ ratio is generally around 0.35. A similar pattern is visible in the distribution of the illite crystallinity (Fig. 3b). Thus, the best crystallinities as expressed by IB values $\leq 0.50$ are found off the Thwaites Glacier and Pine Island Glacier, whereas poorer crystallinities with IB values $>0.56$ are observed on the western ASE shelf. This implies a slightly different composition of the source rocks in the hinterland, with the Getz Ice Shelf delivering somewhat more Mg- and Fe-rich illites, which are less crystalline, and the Thwaites Glacier system and Pine Island Glacier delivering more Al-rich illites, which are more crystalline. Unfortunately the clay mineral data do not allow to better define the geological composition of the respective hinterland.

\section{Clay mineral assemblages in sediments deposited during the last glacial period}

We investigated six sediment cores from the ASE shelf (Figs 1, 4 \& 5) to help identify sources of the clay minerals during the last glacial period, and to determine whether the sediment sources and thus the glacial-time catchment areas were different from today.

In an earlier paper we showed that subglacial recycling of sediments on the continental shelf strongly influences the clay mineral composition of glacial diamictons on the southern Bellingshausen Sea shelf (Hillenbrand et al. 2009b). Palaeo-ice streams eroded old sedimentary strata and mixed this debris together with the debris derived from the West Antarctic hinterland as they advanced across the continental shelf.

As in the Bellingshausen Sea, seismic investigations from the Amundsen Sea shelf indicate that old submarine sedimentary strata crop out near the seafloor and it is probable that these were eroded and reworked as ice advanced across the shelf during the Last Glacial Maximum (Graham et al. 2009, Weigelt et al. 2009). Therefore, we focus specifically on pro-glacial and subglacial sediments that have been recovered from sites near the coast in order to reduce the influence of recycled shelf sediments on the composition of the glacial age sediments.

The investigated sediment cores show three different lithological units that are similar to those already described 
from the ASE (Lowe \& Anderson 2002, Smith et al. 2009, 2011, Hillenbrand et al. 2010) and those described from other Antarctic shelf areas (e.g. Domack et al. 1999, Licht et al. 1999, Evans \& Pudsey 2002, Ó Cofaigh et al. 2005, Hillenbrand et al. 2009b, Reinardy et al. 2009). The lithologies of cores VC415 and PS69/275-1 have been published before (Smith et al. 2009, 2011, Hillenbrand et al. 2010). In summary, the lowermost lithological unit consists of purely terrigenous, massive diamictons, which were deposited subglacially during the last glacial period and at the end of the last glacial period in a pro-glacial setting, respectively. These low shear strength diamictons probably include subglacial "soft" tills as well as sub-ice shelf diamictons and glaciogenic debris flows deposited near the grounding line. The middle lithological unit comprises mainly terrigenous sandy mud, but also sandy gravelly mud, mud intercalated with sand layers and muddy sand. The sediments of this unit probably accumulated in a sub-ice shelf setting or under permanent sea ice coverage proximal to the grounding line. The middle unit thus represents the transition from glacial to post-glacial conditions. The sediments of the uppermost lithological unit generally consist of diatom-bearing or diatomaceous mud and are often bioturbated. They were probably deposited in a seasonally open marine environment and are therefore assumed to be post-glacial in age.

We note that there is a slight difference between the surface clay mineral composition and the composition of the uppermost samples in the gravity and vibro-cores, which may reflect a loss of core tops and/or coring disturbance. We also note that in cores PS69/251-2 and VC417 the typical threefold sequence is not present (Figs $4 \mathrm{a} \& 5 \mathrm{a}$ ). The similarity between the clay mineral composition of the core top of PS69/251-2 and that of the corresponding surface sediment sample suggests that either the transitional unit is missing or that it is merged with the post-glacial unit.

We analysed the clay mineral composition of three sediment cores from the eastern ASE (Fig. 1, Table I). Core PS69/251-2 was recovered offshore of the Abbot Ice Shelf. The Abbot Ice Shelf area was identified as a modern source for smectite (Fig. 2b). In the subglacial and pro-glacial sediments, the smectite content is significantly lower and the kaolinite content significantly higher than in the modern and the post-glacial sediments, while the illite and chlorite contents are very similar (Fig. 4a). Core PS69/300-1 was recovered offshore from Cosgrove Ice Shelf, which is a modern source for smectite and chlorite (Fig. $2 b \&$ c). In the glacial diamictons, the smectite and illite contents are significantly lower than in the modern and post-glacial sediments, whereas kaolinite and chlorite concentrations are significantly higher (Fig. 4b). Core PS69/295-1 was recovered offshore from Pine Island Glacier, which is a major modern source for illite (Fig. 2d). The glacial sediments of this core are represented by only two samples. They show lower illite concentrations but slightly higher kaolinite concentrations than the modern and post-glacial sediments, but similar concentrations to the transitional unit (Fig. 4c).

Thus, the glacial clay mineral signatures in all investigated cores from the eastern ASE are distinctly different from the modern signatures (Fig. 6). Specifically, the kaolinite concentrations of all cores are up to $10 \%$ higher in the subglacial and pro-glacial sediments than in the surface sediments.

We also analysed three sediment cores from the western ASE shelf (Fig. 1, Table I). Core VC417 was recovered offshore from the Dotson Ice Shelf, in an area that is characterized by enhanced chlorite and illite concentrations in the surface sediments (Fig. 2c \& d). In the glacial sediments the illite concentration is drastically lower, while smectite, chlorite and kaolinite concentrations are higher than in modern and post-glacial sediments (Fig. 5a). Core VC415 was recovered offshore from the Getz A Ice Shelf. This region is characterized by enhanced modern smectite concentrations (Fig. 2b), but no major source for a particular clay mineral is obvious. In the glacial sediments, kaolinite, chlorite and illite contents are significantly lower and smectite contents are significantly higher than in the overlying transitional and post-glacial units. In contrast to all other investigated cores, the transitional unit in core VC415 exhibits a clay mineral assemblage that is completely different from both the glacial and the post-glacial assemblages, with minima in smectite and kaolinite and maxima in illite and chlorite contents (Fig. 5b). A similarly 'unique' clay mineral assemblage of the transitional unit was observed in a sediment core from Ronne Entrance in the southern Bellingshausen Sea and explained by a time transgressive deglaciation of the source areas for the various clay mineral assemblages (Hillenbrand et al. 2009b). Core PS69/275-1 was recovered offshore from the Getz B Ice Shelf, where modern sediments show enhanced smectite and illite contents (Fig. 2b \& d), but no major source for a particular clay mineral. The glacial sediments in this core are represented by only two samples. They show significantly lower smectite and slightly lower kaolinite contents, but significantly higher chlorite and slightly higher illite contents than the post-glacial sediments (Fig. 5c).

As observed in the eastern ASE, the clay mineral assemblages in glacial sediments of the western ASE are different from the modern signatures (Fig. 6). However, in contrast to the eastern ASE, the glacial kaolinite contents are only higher in core VC417 north of the Dotson Ice Shelf. This implies that the glaciers that are feeding into the Getz A and B ice shelves today did not supply such significant amounts of kaolinite during glacial times.

Our results show that during the last glacial period high amounts of kaolinite were supplied to the eastern ASE shelf also from outlets other than the Thwaites Glacier. High kaolinite concentration was derived from Pine Island Glacier and from the glaciers draining into the modern 
Cosgrove Ice Shelf and Abbot Ice Shelf. This scenario is consistent with clay mineral assemblages of sediments deposited on the adjacent continental rise during the last glacial period (Hillenbrand et al. 2009a).

In summary, none of the studied cores from the ASE exhibits a glacial clay mineral assemblage that is similar to the modern (Fig. 6). Assuming that recycling of old sediments did not play a major role on the inner shelf (Lowe \& Anderson 2003, Graham et al. 2009, Weigelt et al. 2009), our finding implies that the glaciers and ice streams draining into the ASE must have changed their catchment areas, probably as a result of a migration of the ice divides.

At present, the main western ice divide between the Amundsen Sea and Ross Sea sectors of West Antarctica is migrating towards the Ross Sea at a rate of $c .10 \mathrm{~m} \mathrm{yr}^{-1}$, as a response to long-term and/or short-term forcing (Conway \& Rasmussen 2009). This divide has probably also moved previously, during the Holocene (Neumann et al. 2008). Furthermore, Iizuka et al. (2010) reported a shift of c. $50 \mathrm{~km}$ for the ice divide between the Sôya and the Shirase drainage basins in East Antarctica between the Last Glacial Maximum and the earliest Holocene.

We thus speculate that the transition from the last glacial to the post-glacial period was accompanied by a migration of the ice divides in the hinterland of the ASE. In addition to a movement of the main divide between the Amundsen Sea and the Ross Sea sectors, we assume that the divides between the individual glaciers and ice streams discharging into the ASE also shifted. The glacial to present migration was possibly even more pronounced than that observed at present. Moving ice divides would have changed the geographical extents of the drainage basins of the individual glaciers and ice streams. This would have changed the ratios of the different source rock lithologies eroded and transported at the base of the ice, e.g. subglacial sedimentary strata providing kaolinite vs basement rocks providing illite, and thus resulted in a change of the clay mineral assemblages on the ASE shelf.

The shift in the clay mineral signature between the glacial and the post-glacial sediments could also reflect ice eroding deeper lithological horizons with time and thus delivering different sediments to the shelf. This process, however, probably would produce a more gradational change in the clay mineral assemblages. Furthermore, this process cannot explain that the clay mineral shift occurs at the same stratigraphic level in all cores.

Changes in the intensity of glacial erosion within a drainage basin may be another mechanism explaining the differences between the present and glacial clay mineral assemblages. Wet-based ice is more effective in eroding its bed than dry-based ice (Hallet et al. 1996). During glacial times, when the ice possibly extended to the continental shelf edge, the wet-based areas and hence the areas of greatest erosion may have been located closer to the margin and hence downstream of their modern positions. If upstream and downstream areas of a glacier or ice stream are geologically different, then one should expect differences between the compositions of glacial and modern detritus, even if the positions of ice divides had not changed.

An example of an area, where a migration of the ice divide seems more probable than the movement of the main zone of erosion, is the Kohler Glacier, which, at present, forms only a small distributary of the Smith Glacier flowing northward into Dotson Ice Shelf. The surface sediments offshore from the Kohler Glacier (i.e. offshore from the Dotson Ice Shelf) are dominated by illite (Fig. 6). Evidence from sea floor geomorphology (Graham et al. 2009) indicates that during the last glacial period the Kohler Glacier was an ice stream system much larger than today, probably capturing some of the ice draining through the Smith Glacier today. This scenario could explain the supply of detritus enriched in kaolinite, smectite and chlorite during the last glacial (Fig. 6). As Kohler Glacier has a very small catchment today, there is little potential to explain the changes in the clay mineralogy by shifting the locus of erosion within its catchment.

In summary, our findings have major implications for the reconstruction of sediment provenance in the study area and possibly in other Antarctic regions as well. They indicate that the assignment of glacial sediments to present source regions on the basis of mineralogical and/or geochemical data alone may result in an incorrect reconstruction of palaeo-ice flow patterns (cf. Hillenbrand et al. 2009b), especially in areas where the past drainage configuration of the ice sheet is known to be significantly different to that of the present, e.g. West Antarctica.

\section{Conclusions}

The drainage basin of the Thwaites Glacier system is the most important modern source for kaolinite on the ASE shelf. This indicates the presence of a kaolinite-bearing sedimentary substrate in the Byrd Subglacial Basin and transfer of this material from the hinterland to the ice margin beneath the present-day glacier system. In contrast, the Bentley Subglacial Trench, which is drained by the Pine Island Glacier, hosts the main modern source for illite. Glaciers draining into the Abbot Ice Shelf and Cosgrove Ice Shelf deliver mainly smectite. The modern sediments offshore from the Dotson Ice Shelf and the Getz Ice Shelf show a mixed clay mineral signature and indicate no uniform modern source.

In the ASE clay mineral sources during the last glacial period were different from modern sources, indicating changes in catchment areas of the glaciers and ice streams draining into the ASE. Thus, one has to proceed with caution when reconstructing palaeodrainage patterns based on modern sediment sources in this area.

The distribution of glacial clay mineral assemblages in the ASE shows no consistent pattern, but compared with 
the present-day situation, kaolinite supply to the ASE was generally enhanced.

The indirect evidence for past shifts in the catchment areas of this sector of the WAIS probably indicates a migration of the ice divides. This has major implications for the long-term stability of the ice sheet, because it points towards a dynamically evolving drainage system in the past, similar to that observed today.

\section{Acknowledgements}

We thank the captains, officers, crews, technical staff and shipboard scientists, who helped to make available the sediment samples investigated in this study. The Deutsche Forschungsgemeinschaft provided financial support to WE. Sylvia Dorn is acknowledged for technical assistance in the XRD laboratory. The research is a contribution to the BAS GRADES-QWAD project and the Palaeo-Ice Sheets workpackage. The paper benefited from the constructive criticism provided by two anonymous reviewers and the editor.

\section{References}

ANANDAKRISHNAN, S. \& WinBeRRY, J.P. 2004. Antarctic subglacial sedimentary layer thickness from receiver function analysis. Global and Planetary Change, 42, 167-176.

Bamber, J.L., Riva, R.E.M., Vermeersen, B.L.A. \& LeBrocQ, A.M. 2009. Reassessment of the potential sea level rise from a collapse of the West Antarctic Ice Sheet. Science, 324, 901-903.

Bell, R.E., Studinger, M., Karner, G., Finn, C.A. \& Blankenship, D.A. 2006. Identifying major sedimentary basins beneath the West Antarctic Ice Sheet from aeromagnetic data analysis. In FüTTERER, D.K., DAMASKE, D., Kleinschmidt, G., Miller, H. \& Tessensohn, F., eds. Antarctica: contributions to global earth sciences. Berlin: Springer, 117-121.

BISCAYE, P.E. 1964. Distinction between kaolinite and chlorite in recent sediments by X-ray diffraction. The American Mineralogist, 49, 1281-1289.

BISCAYE, P.E. 1965. Mineralogy and sedimentation of recent deep-sea clay in the Atlantic Ocean and adjacent seas and oceans. Geological Society of America Bulletin, 76, 803-832.

Chamley, H. 1989. Clay sedimentology. Berlin: Springer, 623 pp.

Clarke, T.S., Burkholder, P.D., Smithson, S.B. \& Bentley, C.R. 1997. Optimum seismic shooting and recording parameters and a preliminary crustal model for the Byrd Subglacial Basin, Antarctica. In Ricci, C.A., ed. The Antarctic region: geological evolution and processes. Siena: Terra Antartica Publications, 485-493.

Conway, H. \& Rasmussen, L.A. 2009. Recent thinning and migration of the western divide, central West Antarctica. Geophysical Research Letters, 36, 10.1029/2009GL038072.

Dingle, R.V. \& Lavelle, M. 1998. Late Cretaceous-Cenozoic climatic variations of the northern Antarctic Peninsula: new geochemical evidence and review. Palaeogeography, Palaeoclimatology, Palaeoecology, 141, 215-232.

Domack, E.W., Jacobson, E.A., Shipp, S. \& Anderson, J.B. 1999. Late Pleistocene-Holocene retreat of the West Antarctic ice sheet system in the Ross Sea: Part 2. Sedimentologic and stratigraphic signature. Geological Society of America Bulletin, 111, 1517-1536.

Dunbar, N.W., McIntosh, W.C. \& Esser, R.P 2008. Physical setting and tephrochronology of the summit caldera ice record at Mount Moulton, West Antarctica. Geological Society of America Bulletin, 120, 796-812.
Ehrmann, W., Melles, M., Kuhn, G. \& Grobe, H. 1992. Significance of clay mineral assemblages in the Southern Ocean. Marine Geology, 107, 249-273.

EsQuevin, J. 1969. Influence de la composition chimique des illites sur leur cristallinité. Bulletin du Centre de Recherches de Pau, Société Nationale des Pétroles d'Aquitaine, 3, 147-153.

Evans, J. \& Pudsey, C.J. 2002. Sedimentation associated with Antarctic Peninsula ice shelves: implications for palaeoenvironmental reconstructions of glacimarine sediments. Journal of the Geological Society, 159, 233-238.

Evans, J., Dowdeswell, J.A., Ó Cofaigh, C., Benham, T.J. \& Anderson, J.B. 2006. Extent and dynamics of the West Antarctic Ice Sheet on the outer continental shelf of Pine Island Bay during the last glaciation. Marine Geology, 230, 53-72.

FAGel, N. 2007. Clay minerals, deep circulation and climate. Developments in Marine Geology, 1, 139-184.

Forsberg, C.F., Florindo, F., Grützner, J., Venuti, A. \& Solheim, A. 2008. Sedimentation and aspects of glacial dynamics from physical properties, mineralogy and magnetic properties at ODP Sites 1166 and 1167, Prydz Bay, Antarctica. Palaeogeography, Palaeoclimatology, Palaeoecology, 260, 184-201.

Gingele, F.X., Kuhn, G., Maus, B., Melles, M. \& Schöne, T. 1997. Holocene ice retreat from the Lazarev Sea shelf, East Antarctica. Continental Shelf Research, 17, 137-163.

Graham, A.G.C., Larter, R.D., Gohl, K., Hillenbrand, C.-D., Smith, J.A. \& KunN, G. 2009. Bedform signature of a West Antarctic palaeo-ice stream reveals a multi-temporal record of flow and substrate control. Quaternary Science Reviews, 28, 2774-2793.

Graham, A.G.C., Larter, R.D., Gohl, K., Dowdeswell, J.A., Hillenbrand, C.-D., Smith, J.A., Evans, J., Kuhn, G. \& Deen, T. 2010. Flow and retreat of the Late Quaternary Pine Island-Thwaites palaeo-ice stream, West Antarctica. Journal of Geophysical Research, 115, 10.1029/2009JF001482.

Hallet, G., Hunter, L. \& Bogen, J. 1996. Rates of erosion and sediment evacuation by glaciers: a review of field data and their implications. Global and Planetary Change, 12, 213-235.

Hillenbrand, C.-D. \& Ehrmann, W. 2002. Distribution of clay minerals in drift sediments on the continental rise west of the Antarctic Peninsula, ODP Leg 178, Sites 1095 and 1096. In Barker, P.F., CAmerlenghi, A., Acton, G.D. \& Ramsay, A.T.S., eds. Proceedings of the Ocean Drilling Program, Scientific Results, 178, 1-29.

Hillenbrand, C.-D., Kuhn, G. \& Frederichs, T. 2009a. Record of a MidPleistocene depositional anomaly in West Antarctic continental margin sediments: an indicator for ice sheet collapse? Quaternary Science Reviews, 28, 1147-1159.

Hillenbrand, C.-D., Fütterer, D.K., Grobe, H. \& Frederichs, T. 2002. No evidence for a Pleistocene collapse of the West Antarctic Ice Sheet from continental margin sediments recovered in the Amundsen Sea. Geo-Marine Letters, 22, 51-59.

Hillenbrand, C.-D., Grobe, H., Diekmann, B., Kuhn, G. \& Fütterer, D.K. 2003. Distribution of clay minerals and proxies for productivity in surface sediments of the Bellingshausen and Amundsen seas (West Antarctica) - relation to modern environmental conditions. Marine Geology, 193, 253-271.

Hillenbrand, C.-D., Ehrmann, W., Larter, R.D., Benetti, S., Dowdeswell, J.A., Ó Cofaigh, C., Graham, A.G.C. \& Grobe, H. 2009b. Clay mineral provenance of sediments in the southern Bellingshausen Sea reveals drainage changes of the West Antarctic Ice Sheet during the Late Quaternary. Marine Geology, 265, $1-18$.

Hillenbrand, C.-D., Smith, J.A., Kuhn, G., Esper, O., Gersonde, R., Larter, R.D., Maher, B., Moreton, S.G., Shimmield, T.M. \& Korte, M. 2010. Age assignment of a diatomaceous ooze deposited in the western Amundsen Sea embayment after the Last Glacial Maximum. Journal of Quaternary Science, 25, 280-295. 
Holt, J.W., Blankenship, D.D., Morse, D.L., Young, D.A., Peters, M.E., KempF, S.D., Richter, T.G., Vaughan, D.G. \& CorR, H.F.J. 2006. New boundary conditions for the West Antarctic Ice Sheet: subglacial topography of the Thwaites and Smith glacier catchments. Geophysical Research Letters, 33, 10.1029/2005GL025561.

Iizuka, Y., Miura, H., Iwasaki, S., Maemoku, H., Sawagaki, T., Greve, R., Satake, H., Sasa, K. \& Matsushi, Y. 2010. Evidence of past migration of the ice divide between the Shirase and Sôya drainage basins derived from chemical characteristics. Journal of Glaciology, 56, 395-404.

Larter, R.D., Graham, A.G.C., Gohl, K., Kuhn, G., Hillenbrand, C.-D., Smith, J.A., Deen, T.J. \& Schenke, H.-W. 2009. Subglacial bedforms reveal complex basal regime in a zone of paleo-ice stream convergence, Amundsen Sea embayment, West Antarctica. Geology, 37, 411-414.

LeMasurier, W.E. 2008. Neogene extension and basin deepening in the West Antarctic rift inferred from comparisons with the East African rift and other analogs. Geology, 36, 247-250.

LeMasurier, W.E. \& Rex, D.C. 1991. The Marie Byrd Land volcanic province and its relation to the Cainozoic West Antarctic rift system. In Tingey, R.J., ed. The geology of Antarctica. Oxford: Clarendon Press, 249-284.

LeMasurier, W.E. \& Thomson, J.G., eds. 1990. Volcanoes of the Antarctic plate and the Southern Ocean. Antarctic Research Series, 48, 512 pp.

Licht, K.J., Dunbar, N.W., Andrews, J.T. \& Jennings, A.E. 1999. Distinguishing subglacial till and glacial marine diamictons in the western Ross Sea, Antarctica: implications for a last glacial maximum grounding line. Geological Society of America Bulletin, 111, 91-103.

Lowe, A.L. \& ANDerson, J.B. 2002. Reconstruction of the West Antarctic ice sheet in Pine Island Bay during the Last Glacial Maximum and its subsequent retreat history. Quaternary Science Reviews, 21, 1879-1897.

Lowe, A.L. \& Anderson, J.B. 2003. Evidence for abundant subglacial meltwater beneath the paleo-ice sheet in Pine Island Bay, Antarctica. Journal of Glaciology, 49, 125-138.

Mukasa, S.B. \& Dalziel, I.W.D. 2000. Marie Byrd Land, West Antarctica: evolution of Gondwana's Pacific margin constrained by zircon U-Pb geochronology and feldspar common- $\mathrm{Pb}$ isotopic compositions. Geological Society of America Bulletin, 112, 611-627.

NAYUdU, Y.R. 1971. Lithology and chemistry of surface sediments in sub-Antarctic regions of the Pacific Ocean. Antarctic Research Series, 15, 247-282.

Neumann, T.A., Conway, H., Price, S.F., Waddington, E.D., Catania, G.A. \& Morse, D.L. 2008. Holocene accumulation and ice sheet dynamics in central West Antarctica. Journal of Geophysical Research, 113, 10.1029/2007JF000764.

Ó Cofaigh, C., Dowdeswell, J.A., Allen, C.S., Hiemstra, J., Pudsey, C.J., Evans, J. \& Evans, D.J.A. 2005. Flow dynamics and till genesis associated with a marine-based Antarctic palaeo-ice stream. Quaternary Science Reviews, 24, 709-740.

Oppenheimer, M. 1998. Global warming and the stability of the West Antarctic Ice Sheet. Nature, 393, 325-332.

Pankhurst, R.J., Weaver, S.D., Bradshaw, J.D., Storey, B.C. \& IRELAND, T.R. 1998. Geochronology and geochemistry of pre-Jurassic superterranes in Marie Byrd Land, Antarctica. Journal of Geophysical Research, 103, 2529-2547.

Petschick, R. 2001. MacDiff 4.2.5 Freeware. Frankfurt am Main: Institute of Geology and Palaeontology, Johann Wolfgang Goethe-University. http:// www.geologie.uni-frankfurt.de/Staff/Homepages/Petschick/Petschick.html.

Petschick, R., Kuhn, G. \& Gingele, F. 1996. Clay mineral distribution in surface sediments of the South Atlantic: sources, transport, and relation to oceanography. Marine Geology, 130, 203-229.

Pritchard, H.D., Arthern, R.J., Vaughan, D.G. \& Edwards, L.A. 2009. Extensive dynamic thinning on the margins of the Greenland and Antarctic ice sheets. Nature, 461, 971-975.

Reinardy, B.T.I., Pudsey, C.J., Hillenbrand, C.-D., Murray, T. \& Evans, J. 2009. Contrasting sources for glacial and interglacial shelf sediments used to interpret changing ice flow directions in the Larsen Basin, northern Antarctic Peninsula. Marine Geology, 266, 156-171.
Rignot, E. \& JACOBS, S.S. 2002. Rapid bottom melting widespread near Antarctic Ice Sheet grounding lines. Science, 296, 2020-2023.

Rignot, E., Bamber, J.L., van Den Broeke, M.R., Davis, C., Li, Y., van De Berg, W.J. \& van MeijgaArd, E. 2008. Recent Antarctic ice mass loss from radar interferometry and regional climate modelling. Nature Geoscience, 1, 106-110.

Robert, C. \& Maillot, H. 1990. Paleoenvironments in the Weddell Sea area and Antarctic climates, as deduced from clay mineral associations and geochemical data, ODP Leg 113. In Barker, P.F., Kennett, J.P. et al., eds. Proceedings of the Ocean Drilling Program, Scientific Results, 113, 51-66.

Sснооғ, C. 2007. Ice sheet grounding line dynamics: steady states, stability and hysteresis. Journal of Geophysical Research, 112, 10.1029/ 2006JF000664.

Smith, J.A., Hillenbrand, C.-D., Larter, R.D., Graham, A.G.C. \& Kuhn, G. 2009. The sediment infill of subglacial meltwater channels on the West Antarctic continental shelf. Quaternary Research, 71, 190-200.

Smith, J.A., Hillenbrand, C.-D., Kuhn, G., Larter, R.D., Graham, A.G.C., Ehrmann, W., Moreton, S.G. \& Forwick, M. 2011. Deglacial history of the West Antarctic Ice Sheet in the western Amundsen Sea embayment. Quaternary Science Reviews, 30, 488-505.

Storey, B.C., Pankhurst, R.J., Millar, I.L., Dalziel, I.W.D. \& Grunow, A.M. 1991. A new look at the geology of Thurston Island. In Thomson, M.R.A., Crame, J.A. \& Thomson, J.W., eds. Geological evolution of Antarctica. Cambridge: Cambridge University Press, 399-403.

Studinger, M., Bell, R.E., Blankenship, D.D., Finn, C.A., Arko, R.A., Morse, D.L. \& Joughin, I. 2001. Subglacial sediment: a regional geological template for ice flow in West Antarctica. Geophysical Research Letters, 28, 3493-3496.

Thoma, M., Jenkins, A., Holland, D. \& Jacobs, S. 2008. Modelling circumpolar deep water intrusions on the Amundsen Sea continental shelf, Antarctica. Geophysical Research Letters, 35, 1029/2008GL034939.

Thomas, R., Rignot, E., Casassa, G., Kanagaratnam, P., Acuna, C., Akins, T., Brecher, H., Frederick, E., Gogineni, P., Krabill, W., Manizade, S., Ramamoorthy, H., Rivera, A., Russell, R., Sonntag, J., Swift, R., Yungel, J. \& Zwally, J. 2004. Accelerated sea level rise from West Antarctica. Science, 306, 255-258.

TingeY, J.R. 1991. Commentary on schematic geological map of Antarctica, scale 1:10 000 000. Bureau of Mineral Resources, Australia, Bulletin, No. 238, 30 pp.

VAughan, D.G. 2008. West Antarctic Ice Sheet collapse - the fall and rise of a paradigm. Climatic Change, 91, 65-79.

Vaughan, D.G., Corr, H.F.J., Ferraccioli, F., Frearson, N., O’Hare, A., Mach, D., Holt, J.W., Blankenship, D.D., Morse, D.L. \& Young, D.A. 2006. New boundary conditions for the West Antarctic ice sheet: subglacial topography beneath Pine Island Glacier. Geophysical Research Letters, 33, 10.1029/2005GL025588.

Walker, D.P., Brandon, M.A., Jenkins, A., Allen, J.T., Dowdeswell, J.A. \& Evans, J. 2007. Oceanic heat transport onto the Amundsen Sea shelf through a submarine glacial trough. Geophysical Research Letters, 34, 10.1029/2006GL028154.

Weigelt, E., Gohl, K., Uenzelmann-Neben, G. \& Larter, R.D. 2009. Late Cenozoic ice sheet cyclicity in the western Amundsen Sea embayment evidence from seismic records. Global and Planetary Change, 69, 162-169.

Wellner, J.S., Lowe, A.L., Shipp, S.S. \& Anderson, J.B. 2001. Distribution of glacial geomorphic features on the Antarctic continental shelf and correlation with substrate: implications for ice behavior. Journal of Glaciology, 47, 397-411.

Wilch, T.I., McIntosh, W.C. \& Dunbar, N.W. 1999. Late Quaternary volcanic activity in Marie Byrd Land: potential ${ }^{40} \mathrm{Ar} /{ }^{39} \mathrm{Ar}$ dated time horizons in West Antarctic ice and marine cores. Geological Society of America Bulletin, 111, 1563-1580.

Winberry, J.P. \& AnANDAKrishnan, S. 2004. Crustal structure of the West Antarctic rift system and Marie Byrd Land hotspot. Geology, 32, 977-980. 